\title{
Research on Media Activism: In and Beyond the Film Sphere*
}

\author{
Huang Ting-ting \\ Chongqing University of Art and Science, Chongqing, China
}

\begin{abstract}
For over a century, non-fiction film has figured prominently in the public sphere as a powerful means of persuasion. Among the different types, video activism is a typical one which has been exploring by many scholars. Thus, this article discussed media activism from different spheres. Though this people could figure the difference between video activism and ordinary social documentaries. And also those studies about the function, mechanism, strategies of the video activism provide a foothold for a further study of media activism.
\end{abstract}

Keywords: media activism, video activism, social action, documentary, crisis, democracy

For over a century, non-fiction film has figured prominently in the public sphere as a powerful means of persuasion. Among the different types, video activism is a typical one which has been exploring by many scholars. Strictly, the video activism is a process other than a product. It is using all the available means of persuasion and power to participate in the social movement to prompt change. As such, video making is not perceived as an artistic and creative process alone but, most importantly, as an action for change. Video activism is more than just making a video but includes the processes of screening (accompanied by discussion) and distribution to promote a cause and to mobilize people. It is part of the movement or event and it grows with the event. This is the meaning the author favoured because it marks the difference between video activism and ordinary social documentaries which the documentary could be the final and definitive product.

Since video activism is a process other than a product, maybe it is inadequate to evaluate it only in the film or documentary spheres. Thus, in the first section of this paper, the author adopted some theories from documentary spheres to analysis "video activism" then, for more, the author uses some theories from other disciplines to critique and evaluate the aesthetics of video activism. In this section, firstly, the study showed that the project of the video activism could be considered as a media form. Thus the author explores this term by analyzing the relationship among Crisis, Media, and Democracy.

Secondly, since some other forms of cultural activism exist before video activism, and there must be some common elements between them and video activism, so in this chapter the author explores some other activist arts in order to make some evaluation for video activism. However, can we simply equal the video activist to activist artist or sociopolitical worker? In fact, there is still an ambiguity of activist artist. Maybe know what activists and artists have to offer each other is helpful for us to make clear the term of video activism, and the artistic elements contain in it.

\footnotetext{
* Acknowledgments: First of all, I would like to extend my sincere gratitude to Jimmy Choi who is a Professor in City University of HK taught how to make a research on media activism. High tribute shall be paid to President Li, who has profound knowledge of media and communication gave me some instructive advice and useful suggestions on my thesis. I am also deeply indebted to all the other colleagues and friends who had given their direct and indirect help to me. Finally, I am indebted to my families for their continuous support and encouragement.

Huang Ting-ting, Master, Teacher, Chongqing University of Art and Science.
} 


\section{Evaluation in the Film Spheres}

\section{A Combination of Documentary and Social Action}

Judging by what is shown on the screen, most works of video activism still look like television documentaries or news reporting. This is understandable. Firstly, Some of them are strategically produced for television and film festivals to reach a bigger audience and to get international attention on the issues they care. As such, they have to adopt the styles and formats of the mainstream. Second, except for "video art" which emphasizes more on exploring the medium, video making has not yet developed its own language. It generally applies the theories and techniques of film and television. In fact, many Asian independent video activists gladly acknowledge the influences of Vertov, and progressive Latin American filmmakers in the 60s and 70s etc., In their works we can find traces of cinema verite, direct cinema, Kino-Pravda, the romantic humanism of Flaherty, the social documentary of Grierson, even film essay and experimental documentary etc., However, the characteristics of video and the emphases of activism on participation and advocacy stretch these techniques and genres to the point that they fuse with social action.

Participation is one of the two key features of activism (In that respect, Cinema verite is more relevant though inadequate). The other is Advocacy. It implies action and involvement. Action, in the context of a movement or event, can be direct confrontation on the front line or promotion and mobilization behind the front line. Involvement means becoming part of the event and grows with the event.

\section{Participation}

Participation turns documentary making into social action. Video makers see themselves as activists in the movement and video making as action to support the movement. In their works, there is a sense of the doer in social event that tends to make the presence of the video maker known. Video activists usually are also demonstrators and they stay within the crowd shooting from the crowd while most film and television documentaries will adopt an on looker position shooting from outside at the crowd. This positioning of the camera defines the insider and outsider and what is supposed to be ordinary shooting becomes an act of action-demonstration. Camera is mostly head on or in the crowd and not the third person on-looker position where the camera pans/cuts from one to the other in most documentaries and news reporting. Video activists also use screenings and video makings to promote their cause and to mobilize people. In such cases shooting and viewing become an educating process.

\section{Advocacy}

Advocacy in the context of activism means taking a position and asserting it. When translated to video making, it represents a clear point of standing and an enthusiasm to assert it. Even videos made for television which is supposed to present different points of view will clearly refute opposite opinions in the hands of video activists. "The authoritative, omniscient narrators that usually represent impartiality become an advocate in this kind of videos. The style is usually subjective, agit-prop, and argumentative" (Coyer, Dowmunt, \& Fountain, 2007)

\section{Explore Beyond the Film Sphere}

\section{Crisis \& Media \& Democracy}

According to a definition given by some scholar, Video activism is a kind of social action to effect change. Strictly, it is a process more than a product (Waugh, Baker, \& Winton, 2010, p. 12). Obviously, we can find three critical elements in this definition-Crisis (social action), Media (the production itself), and Democracy 
(the aim to effect change). So in the following part the author prefer to critique video activism through analyzing the relationship among Crisis, Media, and Democracy.

Media plays multiple roles in all societies, such as monitoring the surroundings, social control, and entertainment etc. Scholars have already found innumerable sides to the place occupied or which should be occupied by the media in our societies. And it seems that while crisis happens, the dimension of these roles could reveal its full meaning. But what the hell is Crisis? Crisis can be defined as a disruption, or perceived of social order (Bailey, Cammaerts, \& Carpentier, 2008, p. 46). Defined by some scholars, the term is also used to refer to a decisive or critical turning point in the course of events, as well as a state of affairs in which a decisive change for better or worse is around the corner (Bailey et al., 2008, p. 48).

If the crisis is of great significance for the society, it will necessarily worthy of media attention. The nature of that attention then becomes, itself an element of the crisis (Coyer et al., 2007, p. 102).

In fact, it is crisis that allows a new side of the media to show through. The excitement provoked by a crisis in different sectors of society also reaches the media. The media played an important role as mediator of the crisis by acting as a channel of communication between citizens and the government. While allowing the population to follow the processing of the events as they developed, the media became an active component of the crisis, and was integrate into the whole process.

Then, how should we evaluate the role of those media workers such as the journalists, or video activist? Trace back to the history of different countries, during the process of the socio-political crisis, Journalists' home and offices were searched, and some reporters were arrested by police. Those media workers played a role as partners to the socio-political crisis. They sought, through their positions and decisions to orient the development of the events (Bailey et al., 2008, p. 58). In this process, journalists had even abandoned their positions as observers and became activists in the developing drama.

As it mentioned above, "to effect change" can be simply understood as seeking for democracy or for a better condition of some minorities. Normally, democracy is a concept that implies social justice, equality and political mechanisms for people to participate meaningfully in making the decisions that affect their lives. Democracy implies an ongoing struggle in the political, economic, social and cultural spheres (Kuhn \& Neveu, 2003, p. 30). If as we have argued above, crisis is a structural feature of modern society, and media are the agents of social communication, then the media-crisis relationship becomes a key factor in the struggle for democracy.

According to the statement above, it can be found that media is tend to integrate into the process of social-political movement and be a powerful weapon to struggle for democracy, or for the rights of some certain groups. In fact, a society in crisis also creates a media crisis. The media discussed above should belong to the sphere of Alternative Media. Alternative media is an alternative to mainstream media. It was seen as a supplement to mainstream media, or as a counter critique of the mainstream. If the mass media aim to break up audiences, or see their audiences as "products" to be sold to advertiser, many alternative media attempt to bring people together (Coyer et al., 2007, pp. 121-127). To some extent, the mechanism and techniques of video activism approaches to those of alternative media. A least, through the above analyzing, we got the sociopolitical function of video activism, and we can understand what changes are taking place in the process of turning video making into social action. The sociopolitical function of video activism is obvious; however, what other cultural elements should we consider about video activism? Personally, the author considered that the video activism should inform but not just inform. 


\section{Some Other Forms of Cultural Activism}

Actually, similar forms of cultural activism exist before video activism. In order to find out an aesthetic for video activism, maybe firstly, we should study how these art forms are evaluated.

With one foot in the art world and the other in the world of political activism and community organizing, a remarkable hybrid emerged in the mid-1970s, expanded in the 1980s, and becoming institutionalized in the 1990s. This new activist cultural practice include many forms comprising museum exhibitions, conferences and articles, and museum-sponsored community-based projects (Felshin, 1995, p. 10). It provides program for several magazines and organizations, and it has also led to much critical and theoretical speculation, raising many unanswered questions. In the next section the author will offer an examination of activist art and the artists engaged in it.

The practices examined here are mainly characterized by the innovative use of public space to address issues of sociopolitical and cultural significance, and to encourage community or public participation as a means of effecting social change. while the specific issues vary - the AIDS crisis, homelessness, violence against women, the environment, and racism, among others - the artists share formal strategies, similar methodologies, and intentions. So that what most make this kind of work apart from other political art is not its content, but its methodologies, formal strategies, and activist goals (Felshin, 1995, pp. 14-16).

Activist art, in both its forms and methods, is process-rather than object-or product-oriented, and it usually takes place in public sites rather than some special venues for arts. As a practice, it often takes the form of temporal interventions, such as performance or performance-based activities, exhibitions, media events, and installations (Felshin, 1995, p. 28).

The formal strategies of Activist art including public participation, collaboration among artists, and the employment of media technology in information deliver which successfully embody and serve the work's activist goals. Activist cultural practices are typically collaborative. When activist artists extend the collaborative way of working to a community or an audience, the process takes the form of a similarly inclusive activity_public participation (Kester, 1998, p. 13). This type of participation is a critical promotion for change, and also a potential strategy to activate both individuals and communities. As it showed above, similarly to the other activist cultural practice, video activism is also defined as a process rather than object-or product-oriented, and need collaboration and public participation as a means of effecting social change. But another question was raised: How can we evaluate the aesthetics of discussion, demonstration, and actions which contain in the process of video activism making? Can we consider these as arts? Maybe we could approach to the answers to some extent through analyzing conceptual art.

Different with some other art forms, conceptual art contempt for the art object and its commodity-driven delivery system, its desire to expand aesthetic boundaries, and its emphasis on ideas over physical form or visual definition, led conceptual artists to experiment with all manner of impermanent, cheap, and reproducible materials and forms (Felshin, 1995, pp. 54-57). Many of Conceptual art's strategies, including photocopies and other communication systems, instructions (to be executed by others), installation, video, and performance work, as well as deliberately instant projects, were rooted in the "real world" (Kester, 1998, p. 29). The projects often demanded a degree of viewer participation and frequently occurred outside of traditional art venues.

Conceptual art supposed that the meaning of a work consists not in the autonomous object, but its contextual framework (Thus, the aesthetics of discussion, demonstration, and actions in video activism may 
also be evaluated as a whole). For conceptual art, the viewer is no longer a passive spectator, but became an active participant whose spatial perceptions could be altered by his or her interaction with the work (Felshin, 1995, p. 96). Similarly, the study showed that the video activism can also evoke more people to Concern or participate in the work, or even became an activist themselves.

Another art movement that emerged in the democratic, creative climate of the late 1960s is performance art. Activist artists employ performative activities for many reasons, but often because their openness and immediacy invites public participation and can act as a magnet for the media (Kester, 1998, p. 59).

For activist artists, it's no longer simply a matter of adopting democratic aesthetic strategies, or embracing social and political subject matter in a critique of representation within the confines of the art world. Instead, activist artists have created a cultural form that adapts and activate elements of each of these critical aesthetic practices, and unit them organically with elements of activism and community organizing (Kester, 1998, p. 81). These artists engage in and promote the process of representation, struggle to empower individuals and communities, and ultimately to stimulate social change.

But do they succeed? It is not easy for us to evaluate the effects of projects that often strive for difficult to measure results like raising consciousness, stimulating discussion, or empowering a community? If these goals increase in the process of social change, it is critical for activist artists to establish relationships and mechanisms within the community of their projects to help ensure a long-term impact of their work. This is particularly important for those activist artists who undertake their work in other cities or countries. In other words, the activist artist should identify people in the local community who will sustain the impact of their effort (This is also should be regarded by the video activist). Regardless of the strategies, activist artists will be most effective if they take an active role in sustaining the public participation process in which their work has set in motion (Kester, 1998, pp. 126-130). In fact, the video activist plays a very role in the process of video activism. They are participatory more than just an observer or a recorder.

\section{Activist \& Artist}

However, there is still an ambiguity of activist artist. Maybe know what activists and artists have to offer each other is helpful for us to make clear the term of video activism, and the artistic elements contain in it.

Firstly, we should figure out the definition of activist? The term Activist often sounds misleading because of that word with -ist often implies belief about how things are and ought to be (like feminist, socialist, environmentalist etc.) (Felshin, 1995, p. 18). But, an activist is a different sort of -ist, for it's not your beliefs that make you one but your beliefs hooking up to your activities. An activist refuses to take the world for granted. Faced with evil and pain, the activist does not rage or regret or sigh, also they does not just believe or wish or declare but thinks. Sure enough, each individual is not an outsider to the world, and the world with its beauty, endangerments and wonders is not an outsider to everybody. History is not (or not only) something that other people do, actions of us is the core of the matter. So activist, if not a lovely word, is a useful one. Because it reminds us that the world not only "is" but should be made (Felshin, 1995, p. 20).

Let us imagine that how would the world be without agitators? If so, the great ideals are difficult to stand a chance. Mirror from the history, without a raging activist movement, the confederacy would not have abolished slavery. The minimum wage, the eight-hour day, Social Security, public funding for medical care and higher education, rain forests, clean water etc. were still striving in dreaming. However, if we talk about the mechanism of activist movement, we can not ignore the relationship between activists and artists. 
Activists use and consume art, and artists live in a real world which they find ways to engage and transform (Waugh et al., 2010, p. 24). In fact, the video activist movement really has tried to bring these two spheres together. What is an artist? Artists normally identify themselves as artists other than journalists, or documentarians, and most important not as propagandists. However, we needn't reject that if we spend our lives doing as artists, then we are both separate from and equal to these roles.

"Art, as much as activism, is about articulating visions: the discovery of our own voices through innovations that are inextricably linked with tradition" (Felshin, 1995, p. 13). There is nothing romantic or inherently mystical about this process: We locate ourselves in sympathetic social scenes, articulate our ideas among ourselves, and then test and refine these ideas in the world of actual practice (Waugh et al., 2010, p. 35).

In the Western tradition, it often dictates that artists look inward, where activists look outward (Felshin, 1995, p. 26). However, much as they draws on existing art movements or real life events, the social contribution of the artists lies wholly in their individual creative voice. This is the key dilemma that we must address: How can such action be redefined appropriately as activism?

People tend to simply believe that the true activism is about binding our personal struggles together, not just helping the needy. If you believe so, then you're half-way to an answer. Mastering our own voice doesn't have to mean living in a bubble. We can draw inspiration and energy through many ways like our social participation, and with the works we composed (Felshin, 1995, p. 142).

However, we should awareness that culture is a formative activity, other than a by-product (Felshin, 1995, p. 145). Through drawing individual visions out of a common artistic heritage, people are engaging in the process of defining themselves and the world. And the truth is that while we are setting the terms by which we can understand, we change our lives as well.

In this way, an activist can assess why some filmmakers might reject the role of propagandist. The reason is because that it reduces us, as human beings, to media. John Grierson once defined art as a vehicle for ideology, a tool for the construction of consensus and hence of community or, rather, "national feeling"-all mixed together as a passionate belief of the potential audience (Barsam, 1992, p. 17).

It's undeniable that today, Video activism has become an overwhelmingly dominant mode in socially-committed video. But it has a troubling tendency to first overlook, and then reproduce, thus the values are unexamined. Certainly activist documentaries are often successful on their own functional terms. And sometimes they are also successful in artistic terms. However, why we accept that video activism should be defined so narrowly that it surrounds documentary and nothing else? We may think of the following questions: Should we restrict historical novelists to literal transcripts? Do we set out to write the protest songs without a melody? Why we set up such arbitrary limits for our creative diversity?

The word "diversity" is not chosen lightly, by allowing a single aesthetic to dominate our cultural productions, activist cultural workers tend to exclude humanity from participation. We can find that poor people, children, and some other quite normal populations don't usually go to the movies so that relatively affluent video makers can explain to them the problems of the world. In fact, the problem doesn't exist in our message, but in the assumptions of the old even pedantry documentary tradition, and in which filmmakers must unpack if they want to avoid their reproduction (Barsam, 1992, p. 34).

The failure of many activist video seems to be the lack of any basis of aesthetic unity among its makers. This may be caused by a misapplication of the ideal of diversity; or may because that the consideration of the issue just hasn't been integrated into the methods of production (Waug et al., 2010, p. 210). While solutions 
may turn out to be surprisingly simple, actually figuring them out is pretty difficult. After all, if we reject film as it stands, how do we learn to use it? This is the challenge that all activist experimentalists will face.

As artists they may find that the social movements will not quite know what to do with them. Thus, they become difficult to organize. Actually, there is no reason to expect the broad activist community to define the work for them. They identified themselves as artists, thus must define autonomous methods of organizing that neither subject them nor isolate them to any but the most rational and sympathetic pressures (Kester, 1998, p. 156). Having done this, they must try to persuade activist movements to consider and relate to the work that they do in its fullest sense, not just for its short-term utility. If you love and value art, then there should be a place for it in your movement too.

\section{Conclusion}

According to the statement above, we could figure the difference between video activism and ordinary social documentaries. And also we know more about the function, mechanism, strategies of the video activism by exploring the crisis-media-democracy frame-work. And through introducing some other waves of cultural activism and activist art forms, we could find out some artistic aesthetics of video activism. Know what the artist and activist should offer each other may offer a direction for those video makers to improve their future work. Although there are still some limitations and some unsettled problems exist among these analyzing.

\section{References}

Bailey, O., Cammaerts, B., \& Carpentier, N. (2008). Understanding alternative media. USA: Open University Press.

Barsam, R. (1992). Nonfiction Film A Critical History. Indiana: Indiana University Press.

Choudry, A., \& Kapoor, D. (2010). Learning from the ground up: Global perspectives on social movements and knowledge production. New York: Palgrave Macmillan.

Coyer, K., Dowmunt, T., \& Fountain, A. (2007). The alternative media handbook. London; New York: Routledge.

Felshin, N. (1995). But is it art? The spirit of art as activism. Seattle: Bay Press.

Gitlin, T. (2003). Letters to a young activist. New York: Basic Books.

Kester, G. (1998). Art, activism, and oppositinality: Essays from Afterimage. Durham: Duke University Press.

Kuhn, R., \& Neveu, E. (2003). Political journalism: New challenges, new practices. London; New York: Routledge.

Raboy, M., \& Dagenais, B. (1992). Media, crisis and democracy. London: SAGE Publications.

Waltz, M. (2005). Alternative and activist media. Edinburgh: Edinburgh University Press.

Waugh, T., Baker, M., \& Winton, E. (2010). Challenge for Change: Video activism at the National Film Board of Canada. Montreal: McGill-Queen's University Press. 